\title{
Local abundance and spatial distribution of some migratory birds during post-breeding period
}

\author{
JózSef Gyurácz ${ }^{1}$, SÁNDOR KaLmÁr ${ }^{1} \&$ RéKa Baráth ${ }^{2}$
}

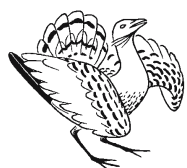

József Gyurácz, Sándor Kalmár \& Réka Baráth 2012. Local abundance and spatial distribution of some migratory birds during post-breeding period. - Ornis Hungarica 20(1): 50-58. Chesty colta, Blue tit Parus caeruleus, Great tit P. major) were studied in a West Hungariclumped distribution both int-breeding season. The dispergation index of all migratory bird species revealed (abb. LACY). According to the PCA the spatial occurrences of Blackcap, Blue tit and Great tit captured in LACY showed significantly higher concentration than of those migrating in SACY. The studied species appeared in all four habitats (bushy, forest, grassland, marsh) of the study stopover area, but their clumped spatial distribution showed habitat preference. The abundance-dependent shift of habitat selection was found only in Great tit, the most of them captured in SACY concentrated in grassland with bushy, while the ones captured in LACY grouped in forest habitat type. Blackcaps were grouped the grassland with bushes habitat type where many Dwarf elder (Sambucus ebulus) bushes were available during autumn migration.

Keywords: stopover birds, annual capture, habitat selection

Összefoglalás Jelen tanulmány öt rövid- és középtávú vonuló, vonulását napközben megszakító énekesmadár faj (vörösbegy Erithacus rubecula, barátposzáta Sylvia atricapilla, csilpcsalpfüzike Phylloscopus collybita, kék cinege Parus caeruleus, széncinege $P$. major) egyedszáma (éves fogás) és térbeli eloszlása közötti kapcsolatot vizsgálja az őszi vonulási időszakban, nyugat-magyarországi élőhelyen. A diszpergáltsági index értékei alapján a madarak csoportos eloszlást mutattak a legkisebb (SACY) és a legnagyobb (LACY) fogásszámú évben is. A PCA eredményei alapján a barátposzáták, a kék cinegék és a széncinegék csoportosulásának mértéke lényegesen nagyobb volt a nagy fogásszámú években. A vizsgált fajok megjelentek mind a négy élőhelyen (bokros terület, erdő, gyep, mocsár) a vizsgálati területen, de az egyedek csoportosulása élőhelypreferenciát mutatott. Az élőhelyválasztásban megmutatkozó denzitásfüggő eltolódást csak a széncinegék esetében sikerült kimutatnunk: a legkisebb fogásszámú évben az egyedek többsége a füves-bokros élőhelyeken koncentrálódott, míg a legnagyobb fogásszámú évben az erdei élőhelyen csoportosultak a madarak. A barátposzáták a füves-bokros élőhelyen koncentrálódtak, ahol a táplálékul szolgáló földi bodza nagy mennyiségben állt rendelkezésükre.

Kulcsszavak: vonuló madarak, éves fogás, élőhely-választás

${ }^{1}$ Institute of Biology, Faculty of Sciences, University of West Hungary, Szombathely, Károlyi Gáspár tér 4. H-9700, Hungary, e-mail: gyjozsi@ttk.nyme.hu, ${ }^{2} I s t v a ́ n$ Chernel Ornithological and Nature Conservation Society, Szombathely, Károlyi Gáspár tér 4. H-9700, Hungary 


\section{Introduction}

The spatial distribution of migrants is an important population factor in their stopover (Chernetsov 2002). Understanding the distribution and abundance of migratory birds is critical for the effective conservation strategy and comprises the core of bird ecology (Caughley \& Sinclair 1994, Krebs 1994, Johnson \& Sherry 2001). The distribution of birds among habitat types is particularly important because the conservation of migratory populations is usually realized by management of their habitats (Morrison et al. 1998).

Migratory birds move among habitats more than residents and are frequent subjects for stopover studies (Cody 1985). Although most studies of migratory bird habitat selection has focused on breeding populations, a simpler situation exists with birds during migration period, when they are free from bothering factors connected with nesting (Hutto 1985). The spatial distribution of migrants could be determined by vegetation structure (Preiszner \& Csörgő 2008), prey availability (Levey \& Stiles 1992, Sherry \& Holmes 1996), predation risks (Rappole et al. 1989), habitat preferences from the breeding period (Morse 1971, Hutto 1980), evolutionary responses to paleoecological circumstances (Johnson \& Sherry 2001), competition and population abundance (Greenberg 1986, Leisler 1992, Marra 2000). Density of intra- and interspecific competitors may effect habitat quality and thus the pattern of spatial distribution and habitat selection by stopover birds (Moore \& Yong 1991). Most of the passerine migrants use stopover sites in a clearly non-random manner, even if many species have broader habitat preference during migration than during breeding (Chernetsov 2006). For example the stopover Robins establish small home ranges and do not move randomly across a large area during their autumn migration (Titov 1999a).

We studied the local abundance and spatial distribution of the short- to mediumdistance migratory and daytime stopover passerines (Robin Erithacus rubecula abb. ERIRUB, Blackcap Sylvia atricapilla abb. SYLATR, Chiffchaff Phylloscopus collybita abb. PHYCOL, Blue tit Parus caeruleus abb. PARCAE, Great tit P. major abb. PARMAJ) in a stopover ground during post-breeding season. Our expectation was that the pattern of spatial distribution of bird species would differ between years when bird abundance was different.

\section{Material and methods}

\section{Study site}

The study was carried out at Tömörd Bird Ringing Station in West Hungary (4721'23'N 1640'04'E), located 15 kilometres from Szombathely. There were four natural habitat types around the station ( $F i$ gure 1). These habitats were characterized according to the SE European Bird Migration Network (Busse 2000) (see below) as follows.

Bushes: Bushes and herbs were made up a compact, dense vegetation, which were dissected by small grass patches. Its characteristic plants were: Blackthorn (Prunus spinosa), Common hawthorn (Crataegus monogyna), Wild pear (Pyrus pyraster), Wild rose (Rosa canina). There were great variety of crops but there was not management in the bushes. The height of vegetation was 2-3 meters. 


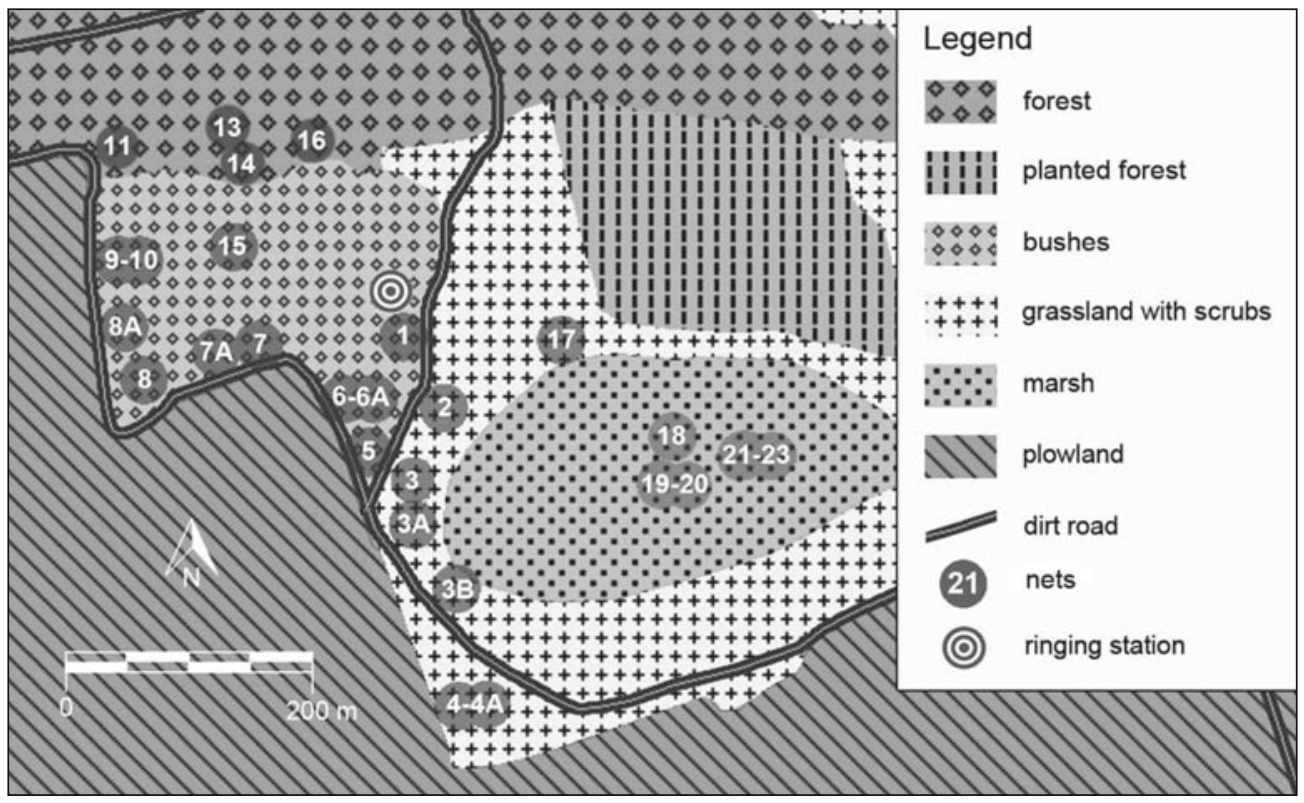

Figure 1. Habitat map of the study area with the locations of nets

1. ábra A vizsgálati terület élőhely-térképe hálóhelyekkel

Forest: Broadleaf trees and bushes show a compact, dense edge vegetation, forming an ecoton community with Turkey oak (Quercus cerris), Blackthorn, Common hawthorn, Wild pear as characteristic plants. There were plenty of crops and normal forestry management in the forest. The height of vegetation was 6-7 meters.

Grassland with scrubs: This habitat type made a transition between the wet habitats of the swamp and the steppe communities that used to cover the croplands around the marsh. There were a few bushes in the grassland, with two small patches of Dwarf elder (Sambucus ebulus). There grassland was not managed.

Marsh: It was a small (6 ha) permanent and an isolated wetland. Characteristic plants were Reedmace (Typha latifolia) and Rush (Schoenoplactus lacustris) in the marsh. The height of vegetation was 1-2 meters. Water was supplied to the marsh only by precipitation. The marsh dried out and marsh vegetation was degraded because of scarce rainfall in 2000 and 2001.

\section{Field work}

The birds were captured and ringed at the Tömörd Bird Ringing Station between 1998 and 2011. Bird ringing took place during the post-breeding period (dispersion and autumn migration), from the third decade of July to the first decade of November, 95-100 ringing days each year. For catching the birds we used 28 numbered mist-nets (12 meter long and 2.5 meter high with 5 shelves and a mesh size of $16 \mathrm{~mm}$ ). There was a line of six nets in the deepest part of the marsh. Four nets were in the forest, eleven in the bushes and seven in the grassland. Birds had been captured from dawn to dusk, except on rainy and stormy days. All birds were ringed and aged according to Svensson (1992). The birds 


\begin{tabular}{|c|c|c|c|c|c|c|c|c|c|c|}
\hline & \multicolumn{2}{|c|}{ ERIRUB } & \multicolumn{2}{c|}{ SYLATR } & \multicolumn{2}{c|}{ PHYCOL } & \multicolumn{2}{c|}{ PARCAE } & \multicolumn{2}{c|}{ PARMAJ } \\
\hline Year & 2003 & 2007 & 2002 & 2009 & 2002 & 2004 & 2003 & 2004 & 2006 & 2010 \\
\hline $\boldsymbol{A C}$ & 565 & 911 & 393 & 1132 & 237 & 558 & 119 & 1040 & 141 & 958 \\
\hline $\boldsymbol{D}$ & 19.48 & 31.41 & 13.55 & 39.03 & 8.17 & 19.24 & 4.10 & 35.86 & 4.86 & 33.03 \\
\hline $\boldsymbol{V}$ & 312.62 & 402.25 & 136.54 & 1753.53 & 59.08 & 235.90 & 29.81 & 5477.91 & 26.55 & 2055.82 \\
\hline $\boldsymbol{S D}$ & 17.68 & 20.06 & 11.69 & 41.88 & 7.69 & 15.36 & 5.46 & 74.01 & 5.15 & 45.34 \\
\hline DI & 16.05 & 12.81 & 10.08 & 44.92 & 7.23 & 12.26 & 7.26 & 152.75 & 5.46 & 62.23 \\
\hline $\boldsymbol{X}^{2}$-test & 205.09 & 230.26 & 26.32 & 712.26 & 59.71 & 81.09 & 25.37 & 1344.00 & 43.97 & 306.62 \\
\hline $\boldsymbol{P}$ & \multicolumn{10}{|c|}{$<0.001$} \\
\hline
\end{tabular}

Table 1. Annual captures (AC), density (D), variance (V), standard deviation (SD) and dispergation index (DI) of bird species. (See the introduction for species abbreviations.) The results of $X^{2}$-test and significance level $(P)$ relate to the dispergation index (DI)

1. táblázat A madárfajok évi fogása (AC), denzitása (D), varianciája (V), szórása (SD), és diszpergáltsági indexe (DI). (A fajnevek rövidítését Id. a bevezetésben.) A $X^{2}$-teszt és a szignifikanciaszint $(P)$ értékei a diszpergáltsági indexre vonatkoznak

were weighed to the nearest $0.1 \mathrm{~g}$ (using a spring balance) and the fat reserves (fat index, condition) were estimated visually according to SE European Bird Migration Network protocol (Busse 2000) - ranging from 0 (no fat) to 8 (bulging fat).

\section{Data processing and statistical analysis}

From the 13 study years we selected the „smallest annual capture year” (abb. SACY) and the "largest annual capture year” (abb. LACY) for all the five selected bird species. Table 1 shows the annual captures of the selected years. We used the number of caught birds (only birds with net number) per year and per net of five bird species. The first-year and adult birds were not separated in the statistical analysis. To determine the spatial distribution of bird population in SACY and LACY we used the dispergation index. It was calculated as $D I=s^{2} / d$, where $s^{2}$ is variance of number of caught/net/year, $\mathrm{d}$ is density, average number of caught/net/ year. We tested the spatial distribution (DI) of birds caught by nets were standing in different habitat types with $X^{2}$-test. Chi square supplies us with a method for determining if a sample variance is significantly greater than or less than the average (Fowler \& Cohen 1991, Moskát et al. 1992). We compared the mean body mass and condition of birds in SACY and LACY by Student t-test (Fowler \& Cohen 1991).

We used principal component analysis (PCA) on number of caught birds in the four habitat types in SACY and LACY, to examine correlations among spatial distribution of birds and habitat types (Podani 1997). Statistical analyses were carried out by the PAST software version 1.38 (Hammer et al. 2006).

\section{Results}

The dispergation index of all migratory bird species revealed clumped distribution $(D I>1)$ in both SACY and LACY (Table 1), but according to the PCA the spatial occurrences of Blackcap, Blue tit and Great tit captured in LACY showed significantly higher concentration than of those migrating in SACY (Figure 2). The most Blackcaps 


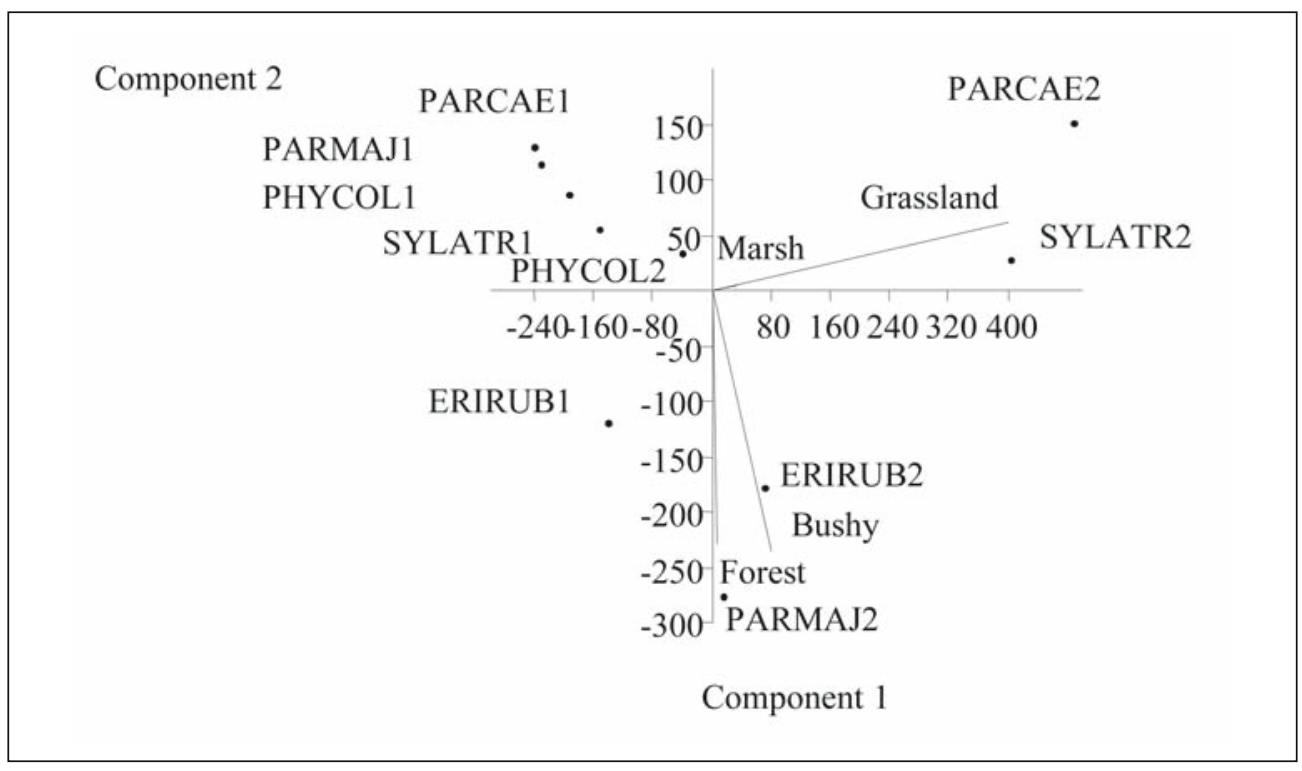

Figure 2. Principal component analysis ordination of bird distribution pattern in SACY (1) and LACY (2) over four habitat types: forest, bushy, grassland with scrubs, marsh. The first component explains $72.33 \%$ of the data variability, the second component $22.47 \%$, the third component $4.58 \%$ and the fourth component only $0.61 \%$

2. ábra A madárfajok főkomponens-analízis ordinációja a kis $(S A C Y=1)$ és nagy fogású $(L A C Y=2)$ évek és élőhely-típusok (erdő, bokros, bokros-gyep, mocsár) alapján. Az első főkomponens az adatok varianciájának 72,33 , a második 22,47 , a harmadik 4,58, a negyedik mindössze 0,61 százalékára ad magyarázatot

and Blue tits clumped in grassland habitat type both in SACY and LACY, but the most Great tits were captured in grassland during SACY and most of them were captured in forest during LACY (Figure 3).

The average fat index and body mass of Robins caught in LACY was significantly smaller than of those migrating in SACY. The average fat index of Blackcaps, Blue tits and Great tits caught in LACY were significantly larger than of those migrating in SACY. The mean condition and body mass of Chiffchaffs, as well as mean body mass of Blue tits migrating in SACY and LACY did not differ significantly. The average body mass of Blackcaps and Great tits caught in LACY were significantly larger than of those migrating in SACY (t-test, Table 2).

\section{Discussion}

The spatial distribution of all five species showed clumped distribution at the study stopover site during post-breeding period. The spatial concentration of individuals could be explained by unequal food resource and refuge site distribution because the habitat selection during stopovers should be aimed achieving the two of the most important goals: to maximize the fuel deposition rate and to minimize the risk of predation (Alerstam \& Lindström 1990). Another factor that can strongly effect spatial distribution and habitat selection of stopover birds is prey-based intraspecific competition (Moor \& Yong 1991), which depends on the abundance of birds. Our results sup- 


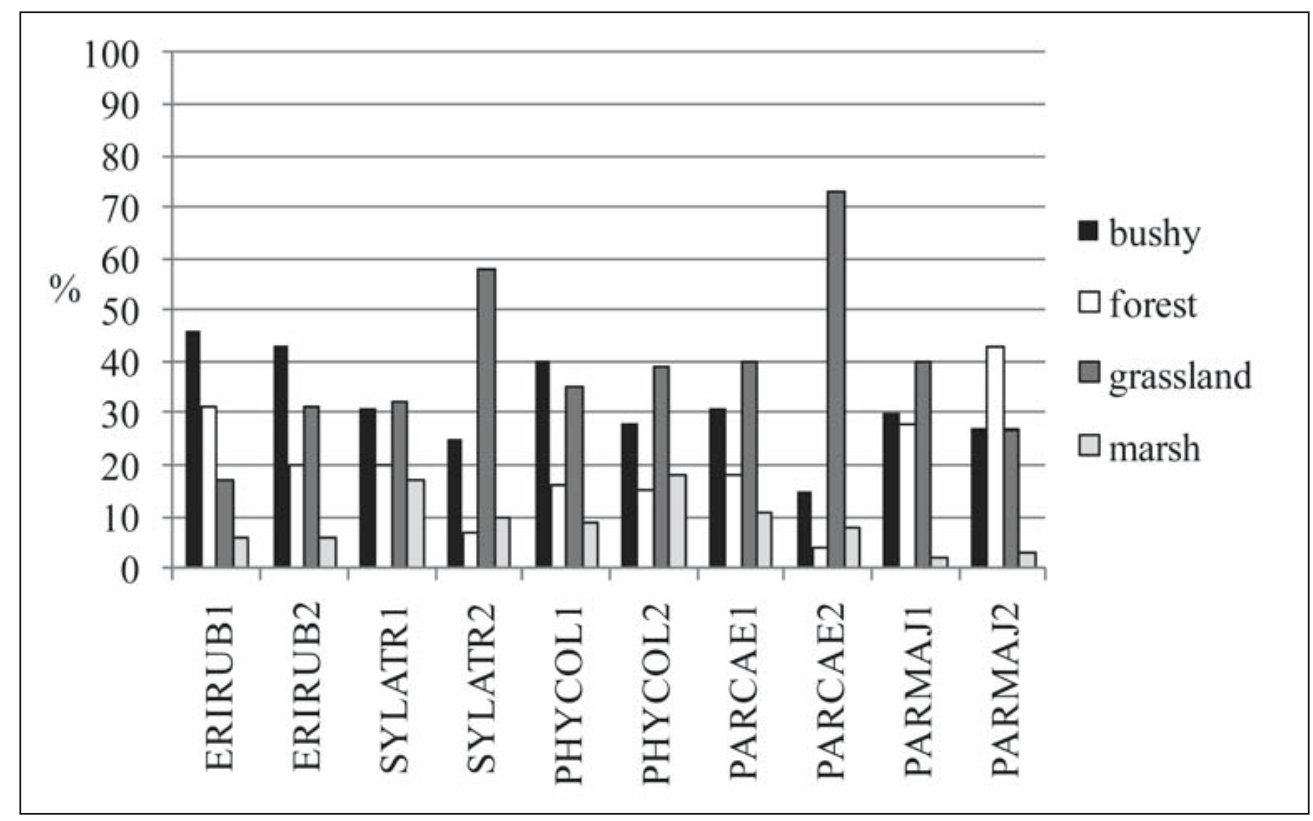

Figure 3. Distribution of the percentages (\%) of annual captures in SACY and LACY according to habitat types

3.ábra A befogott madarak százalékos aránya élőhely-típusok szerint a legkisebb (SACY) és legnagyobb (LACY) fogásszámú években

\begin{tabular}{|l|c|c|c|c|c|}
\hline & \multicolumn{2}{c|}{ Mean \pm S.D. } & t-test & df & P \\
\hline fat & SACY & LACY & & & \\
\hline ERIRUB & $1.80 \pm 1.41$ & $1.40 \pm 1.23$ & 5.61 & 1476 & $<0.01$ \\
\hline SYLATR & $1.44 \pm 0.50$ & $1.50 \pm 0.75$ & -2.1 & 1326 & $<0.05$ \\
\hline PHYCOL & $1.32 \pm 1.39$ & $1.51 \pm 1.21$ & -1.84 & 790 & NS \\
\hline PARCAE & $0.93 \pm 0.79$ & $1.45 \pm 1.25$ & -6.25 & 1154 & $<0.01$ \\
\hline PARMAJ & $1.16 \pm 0.72$ & $2.83 \pm 1.19$ & -23.10 & 1097 & $<0.001$ \\
\hline body mass & $16.47 \pm 1.39$ & $16.19 \pm 1.25$ & 3.99 & 1466 & $<0.01$ \\
\hline ERIRUB & $18.00 \pm 1.38$ & $18.26 \pm 1.48$ & -3.12 & 1499 & $<0.01$ \\
\hline SYLATR & $7.45 \pm 0.67$ & $7.40 \pm 0.76$ & 0.83 & 770 & NS \\
\hline PHYCOL & $10.82 \pm 0.66$ & $10.88 \pm 0.67$ & -0.92 & 1065 & NS \\
\hline PARCAE & $17.40 \pm 1.12$ & $18.03 \pm 1.24$ & -6.07 & 1082 & $<0.01$ \\
\hline PARMAJ & & & & & \\
\hline
\end{tabular}

Table 2. Mean fat index (condition) and body mass of bird species in SACY and LACY

2. táblázat A madárfajok átlagos vonulási zsírtartaléka (kondíció) és testtömege a legkisebb (SACY) és legnagyobb fogásszámú (LACY) években 
port the strong influence of local abundance on the spatial distribution of Blackcap, Blue tit and Great tit migratory populations, which stopovered at the study site during post-breeding period. Higher proportion of stopover Blackcaps, Blue tits and Great tits were captured in LACY by nets in grassland as well as forest habitat type than of those captured in SACY. The recapture rates showed that most migratory Blackcaps, Blue tits and Great tits captured stopover only 1-2 days at the study area in September and October (Gyurácz \& Bánhidi 2008). The most migratory individuals with larger fat reserve and body mass in LACY could continue their autumn migration after short stopover. The Robin, Chiffchaff and Blackcap were dominant and regular migrant and stopover species during autumn at the study area. By contrast, the Blue tit and Great tit had intensive migration in 2004 or 2010. The bulk migration of the tits could be in relation with less beech crop and the number of tits breeding in Alps and Carpathians as well as areas north from Hungary (Smith \& Nilsson 1987, Nowakowski \& Vähätalo 2003, Nyquist 2007). Flocking behaviour of the wintering birds was expected to relate inversely to food supply of habitat (Grubb 1987, Székely \& Juhász 1993). Although the most Blue tits were captured in grassland with scrub, the forest and the bushy habitat types were better habitats in terms of feeding and fat accumulation, than the grassland with scrub and the marsh (Gyurácz et al. 2011). Some migrant species were known to establish defined home range or temporary territory within the suitable habitat during stopover (Chernetsov 2005). We suggest the territorial spacing of Blue tits may prevent the formation of large flocks during their stopover time in the local forest and bushy. Significantly more tits were displaced to poorer grassland with scrub during the intensive migration (2004) than during the weak migration (2003).

The spatial distribution of Blackcaps was related to the patchy distribution of the preferred berries. Blackcaps were grouped in the grassland with bushes habitat type where many Ground elder bushes were available during autumn migration. It previously was shown in Robins and other migratory passerines that the pattern of spatial distribution was related to the distribution of their prey (Titov 1999a, 1999b, Chernetsov \& Titov 2001). The most Robins captured in LACY were leaner because of their fat reserve exhausted during nocturnal migration (Gyimóthy et al. 2011b). The more even distribution of Robins in SACY and LACY compared to distribution of other species could be due to the bulk of the migratory Robins remained within $350 \mathrm{~m}$ during their stopovers in autumn migration (Chernetsov 2005). Titov (1999b) shown that stopover Robins did not start the fat accumulation until they established a small defined stopover home range. These patterns probably also true for Chiffchaffs during stopover.

Habitat selection during post-breeding period varies among species and habitat change after breeding and dispersion is a frequent phenomenon for migrating birds. Usually the migratory passerines seem to use wider habitat during stopovers compared to breeding period, behaving as generalists in the habitat selection (Barlein 1983, Vega Rivera et al. 2003, Chernetsov 2006, Preiszner \& Csörgő 2008). This behaviour reduces intra- and interspecific competition (Berthold 1993). The studied species occurred in all four habitats of the study stopover area, but their clumped spatial distribution showed habitat preference. The Robins were captured in many habitat types in Hun- 
gary during autumn migration but the most Robins occurred in stopover sites surrounding forest and bushy areas (Gyimóthy et al . 2011a). The abundance - dependent shift of habitat selection was found only in Great tit. The most of them captured in SACY concentrated in grassland with bushy, while the ones captured in LACY grouped in forest habitat type. The bushy and forest habitats were supposed primarily refuges for Great tits because the fat reserves of the recaptured tits did not change significantly during their stopovers.

According to the above mentioned results we assumed that local abundance of stopo-

\section{References}

Alerstam, T. \& Lindström, E. 1990. Optimal bird migration: the relative importance of time, energy, and safety. - in: Gwinner, E. (ed.) Bird migration. Physiology and ecophysiology. - Springer, Berlin, Heidelberg, New York pp. 331-351.

Barlein, F. 1983. Habitat selection and associations of species in European passerine birds during southward, post-breeding migration. - Ornis Scandinavica 14: 239-245.

Berthold, P. 1993. Bird migration, a general survey. - Oxford University Press, New York

Busse, P. 2000. Bird Station Manual. - University of Gdansk, Gdansk

Caughley, G. \& Sinclair, A. R. E. 1994. Wildlife Ecology and Management. - Blackwell Scientific Publications, Cambridge

Chernetsov, N. 2002. Spatial behaviour of first-year Blackcaps (Sylvia atricapilla) during the pre-migratory period and during autumn migratory stopovers. - Journal of Ornithology 143: 424-429.

Chernetsov, N. 2005. Spatial behavior of medium and long-distance migrants at stopovers studied by radio tracking. - Annals of the New York Academy of Sciences 1046: 242-252.

Chernetsov, N. 2006. Habitat selection by nocturnal passerine migrants en route: mechanisms and results. - Journal of Ornithology 147: 185-191.

Chernetsov, N. \& Titov, N. 2001. Movement patterns of European reed warblers Acrocephalus scirpaceus and Sedge warblers A. schoenobaenus before and during autumn migration. - Ardea 89: 509-515. ver passerines can be one of the major causes for the observed spatial distribution and habitat shifts beside the interspecific competition and other ecological factors.

\section{Acknowledgements}

We would like to thank to all those who took part in field-work and the members of the BirdLife Hungary for the bird ringing and the data collecting work. The study was partially supported by the University of West Hungary (TÁMOP 4.2.1/B-09/1/KONV2010-0006).

Cody, M. L. 1985. Habitat selection in the Sylviinae warblers of Western Europe and North Africa. - in: Cody, M. L. (ed.) Habitat Selection in Birds. - Academic Press INC., London pp. 86-126.

Fowler, J. \& Cohen, L. 1991. Statistics for ornitologists. - BTO Guide 22., London

Greenberg, R. 1986. Competition in migrant birds in the nonbreeding season. - Current Ornithology 3: 281-307.

Grubb, T. C. Jr. 1987. Changes in the flocking behaviour of wintering English titmice with time, weather and supplementary food. - Animal Behaviour 35: 794-806.

Gyimóthy, Zs., Gyurácz, J., Bank, L., Bánhidi, P., Farkas, R., Németh, Á. \& Csörgő, T. 2011a. Autumn migration of Robins in Hungary. - Biologia 66(3): 1-9.

Gyimóthy, Zs., Gyurácz, J., Bank, L., Bánhidi, P., Farkas, R., Németh, Á. \& Csörgő, T. 2011b. Winglength, body mass and fat reserves of Robins (Erithacus rubecula) during autumn migration in Hungary. - Acta Zoologica Academiae Scientiarum Hungaricae 57(2): 203-218.

Gyurácz, J. \& Bánhidi, P. 2008. Dynamics and spatial distribution of migratory birds. - Nyugat-magyarországi Egyetem, Szombathely

Gyurácz, J., Bánhidi, P. \& Kóródi, A. 2011 Post-breeding movements of Blue tits (Parus caeruleus) in a West Hungarian stopover site. - Ornis Hungarica 19: 21-29.

Hammer, O., Harper, D. A. T., Ryan, P. D. 2006. PAST (Paleontologiacal Statistics Version 1.38), Oslo 
Hutto, R. L. 1980. Winter habitat distribution of migratory land birds in western Mexico, with special reference to small, foliage-gleaning insectivores. - in: Keast, A. \& Morton, E. S. (eds.) Migrant birds in the Neotropics: ecology, behavior, distribution, and conservation. - Smithsonian Institution Press, Washington DC pp. 181-203.

Hutto, R. L. 1985. Habitat selection by nonbreeding, migratory land birds. - in: Cody, M. L. (ed.) Habitat selection in birds - Academic Press INC., London pp. 455-473.

Johnson, M. D. \& Sherry, T. W. 2001. Effects of food availability on the distribution of migratory warblers among habitats in Jamaica. - Journal of Animal Ecology 70: 546-560.

Krebs, C. J. 1994. Ecology: the experimental analysis of distribution and abundance. - Harper Collins Publishers, New York

Leisler, B. 1992. Habitat selection and coexistence of migrants, and Afrotropical residents. - Ibis 134(Suppl. 1): 77-82.

Levey, D. J. \& Stiles, F. G. 1992. Evolutionary precursors of long-distance migration: resource availability and movement patterns in Neotropical landbirds. - American Naturalist 140: 447-476.

Marra, P. P. 2000. The role of behavioral dominance in structuring patterns of habitat occupancy in a migrant bird during the non-breeding period. - Behavioral Ecology 11: 299-308.

Moore, F. R. \& Yong, M. 1991. Evidence of food-based competition among passerine migrants during stopover. - Behavioral Ecology and Sociobiology 28: 85-90.

Morrison, M. L., Marcot, B. C. \& Mannan, R. W. 1998. Wildlife-Habitat Relationships ( $2^{\text {nd }}$ ed.). - University of Wisconsin Press, Madison

Morse, D. H. 1971. Insectivorous birds as an adaptive strategy. - Annual Review of Ecology and Systematics 2: 177-200.

Moskát, Cs., Waliczky, Z. \& Báldi, A. 1992. Dispersion and association of some marshland-nesting birds: a matter of scale. - Acta Zoologica Academiae Scientiarum Hungarica 38(1-2): 47-62.
Nowakowski, J. K. \& Vähätalo, A. V. 2003. Is the Great tit Parus major an irruptive migrant in Northeast Europe? - Ardea 91: 231-244.

Nyquist, L. 2007. Migration patterns of Blue tits ( $\mathrm{Pa}$ rus caeruleus) at Hammarö Bird Observatory. - University essay from Karlstads Universitet

Podani, J. 1997. Bevezetés a többváltozós biológiai adatfeltárás rejtelmeibe. - Scientia Kiadó, Budapest

Preiszner, B. \& Csörgő, T. 2008. Habitat preference of Sylviidae warblers in a fragmented wetland. - Acta Zoologica Academiae Scientiarum Hungaricae 54(Suppl. 1): 111-122.

Rappole, J. H., Ramos, M. A. \& Winker, K. 1989. Wintering Wood thrush movements and mortality in southern Veracruz. - Auk 106: 402-410.

Sherry, T. W. \& Holmes, R. T. 1996. Winter habitat quality, population limitation, and conservation of Neotropical-Nearctic migrant birds. - Ecology 77: 352-383.

Smith, H. G. \& Nilsson, J-A. 1987. Intraspecific variation in migratory pattern of a partial migrant, the Blue tit (Parus caeruleus): an evaluation of different hypothesis. - Auk 104: 109-115.

Svensson, L. 1992. Identification Guide to European Passerines ( $4^{\text {th }}$ ed. $)$. - Naturhistoriska Riksmuséet, Stockholm

Székely, T. \& Juhász, T. 1993. Flocking behaviour of tits (Parus spp.) and associated species: the effect of habitat. - Ornis Hungarica 3: 1-6.

Titov, N. 1999a. Individual home ranges of Robins Erithacus rubecula at stopovers during autumn migration. - Vogelwelt 120: 237-242.

Titov, N. 1999b. Home ranges in two passerine nocturnal migrants at a stopover site in autumn. - Avian Ecology and Behaviour 3: 69-78.

Vega Rivera, J. H., McShea, W. J. \& Rappole, J. H. 2003. Comparison of breeding and postbreeding movements and habitat requirements for the Scarlet tanager (Piranga olivacea) in Virginia. - Auk 120(3): 632-644. 